\title{
The Unheimliche Approach in the Making of Interiors
}

\begin{abstract}
'The (Re)Creative Workings of Existential Anguish in Interior Architecture' aims to understand, and potentially incorporate, the unheimliche into interior-architectural design teaching. My inquiry addresses a paradoxical and disquieting force inside interiors that does not intimidate, but rather stimulates, the growth of imagination and creativity through design. How can one define the limits of one's own certainties and how to overcome them even if they cause existential anguish? I will argue that existential anguish in interiors emerges in the tension between a particular belonging to existing affiliations and the fresh unfamiliarity of unexpected encounters. My inquiry complements prevailing values and norms in interior architecture as preset by society (identity, commodities, light, sight, and so on). Interiorarchitectural unheimlichkeit may engage in a disruptive design approach that triggers and allows the growth of other values, such as empathy, in interior architecture. The unheimliche may specify a small yet existential part of interior architecture as a discipline. How can existential anguish become a (re)creative agency in design teaching? It can be argued that a series of pedagogic experiments entitled 'Onheimelijk Studios', as collectively organized with and by student co-researchers at the St Lucas School of Architecture, Belgium, contributes to the research of existential anguish through the designing and making of interiors.
\end{abstract}

Keywords: unheimliche, anguish, interior architecture, emerging, (re)creative

My ongoing $\mathrm{PhD}$ research project, entitled 'The (Re)Creative Workings of Existential Anguish', aims to explore architectural interiors in a particular state of becoming. One can associate (re)creative workings to this state of becoming or, in other words, something that is 'in the making'. In the unheimliche becoming of the interior, an unforeseen tension occurs that disrupts an anticipated flow of experiences. This tension may twist one's imagination, as it either leads to uneasiness for the beholder or to the reverse. I prefer not to use the Vidlerian notion 'uncanny', but rather the Freudian notion 'the unheimliche', as the latter contains a topical dimension which the uncanny seems to lack.

In this article, two perspectives on the central theme of the unheimliche are important. First, from the viewpoint of interior architecture, I inquire into the (re)creative workings of the unheimliche as a fruitful tension between the apparently contradicting aspirations of belonging and encounter. I hope to demonstrate the disruptive shifts of the imagination in beholding a renowned painting by the Anglo-Swiss artist Henri Füseli (fig.1) by juxtaposing it with the works of Sigmund Freud and Anthony Vidler.

A second perspective discusses the Unheimliche as a particular design approach into interior architectural design education. Inspired by the works of Bernard Tschumi and Heidegger, this approach has formed and informed a series of Research Design Studios, entitled the 'Onheimelijk Studios', organized at the St Lucas School of Architecture between the years 2009-2013. A small artefact (fig.2) 'in the making' came forth and has affected students and my research in perhaps an unbecoming way.

\section{Unheimliche Tension between Belonging and Encounter}

The Unheimliche, or the occurrence of existential anguish in interior architecture, comes forth as it alternates between two primal human aspirations, i.e., belonging and encounter. The first, be-longing ('to properly relate to') existentially addresses the ontological question of an affiliation, desired or not: where does one come from? What is one's provenance and cultural background? This existential belonging points back to particular affinities of one's life. 
Following Sloterdijk's spherical 'spaces of coexistence'(Sloterdijk, 2005), one can argue that every individual seems to be bound to a larger sphere. The sphere defines an ethnic, linguistic or geographical domain to which one can belong: a sphere encloses a heim. As one is affiliated with a sphere, with its respective sets of inherited values and convictions, one is expected to act accordingly. However, one can either accept or reject this home. In the former acceptance of a heim, one becomes attached (to the memory of) a heimliche sphere to which one may return. Hence, existential belonging is framed by pertaining to a world 'that is already there'. One can either choose to accept these existing affiliations or not.

Aside from the urge for existential belonging, there is another, perhaps neglected, aspiration in interior architecture. In the rejection of the heim, one wanders from known and existing patterns. The experiential encounter (Late Latin: incontra, meaning 'in front of') affects the wanderer and discloses unexpected changes during the flow of experiences one goes through. As opposed to existential belonging, which perhaps consolidates one's belonging and identity, an encounter rather expands. The encounter constructs unexpected future possibilities that start to emerge in the tension of what is and could be. The encounter may affect one as it embodies a desired, yet 'uneasy' and unheimliche state of becoming: a world that becomes. Hence, in the tension between belonging and the encounter, a sense of unfamiliarity, and potentially the unheimliche, materializes.

Historically, it was the Austrian neurologist Sigmund Freud who developed the notion of the unheimliche following the insights by author and psychiatrist Ernst Jentsch (1906), who equated the unheimliche to intellectual uncertainty. In his book Das Unheimliche (2003 [1919]), Freud further broadened Jentsch's vision. According to Freud, the locus of the unheimliche is to be found in the area of aesthetics: by repressing the primitive, anguish emerges. After the phase of repression, the unheimliche then resurges, resulting in awkward occurrences: something or someone can be familiar and strange at the same time. Freud then introduces uncanny themes, such as the double, the primitive, inanimate objects coming to life, awkward repetitions, the evil eye, and others. Amongst others, Freud cites from then popular literary sources such as E.T.A Hoffman's 'Die Doppelgänger' (Hoffman, 1821) in order to fathom the unsettling phenomenon of the unheimliche. In so doing, Freud starts recording unheimliche phenomena and induces the primitive, the aberrant and the repulsive into science at the beginning of the $20^{\text {th }}$ century.

Building upon this aforementioned tension between belonging and encounter, I would like to discuss a painting entitled 'The Nightmare' (fig.1), completed in 1781 by Henri Fuseli. The painting is known to convey a sense of anguish to the beholder. At first gaze, the work portrays a nightly domestic scene of a lady dreaming. As one clearly identifies all the actors portrayed, something unforeseen arises out of the shadow. Two eerie figures, a horse and a dwarf, seem to be out of place: they do not belong there. A hideous goblin-like incubus sits upright on the sleeping lady and, with an evil eye, gazes at the viewer: This disfigured creature potentially violates, and hence transgresses, the sense of domesticity. The encounter of a bourgeois interior with primitive and scary figures disturbs the beholder, who uneasily anticipates what comes next. The beholder can only witness and realize mortal danger at hand. This picture assembles a series of unconscious and unheimliche forces that would be later described by authors such as Freud and Vidler.

The unheimliche seems to affect the clarity of judgement and the perception of the beholder to be rather unreliable. The beholder of the portrayed interior becomes knowingly implied as he/she encounters the unheimliche. In a temporary estrangement from the world, the beholder wonders, doubts, and finally becomes engaged in the painted scene. 


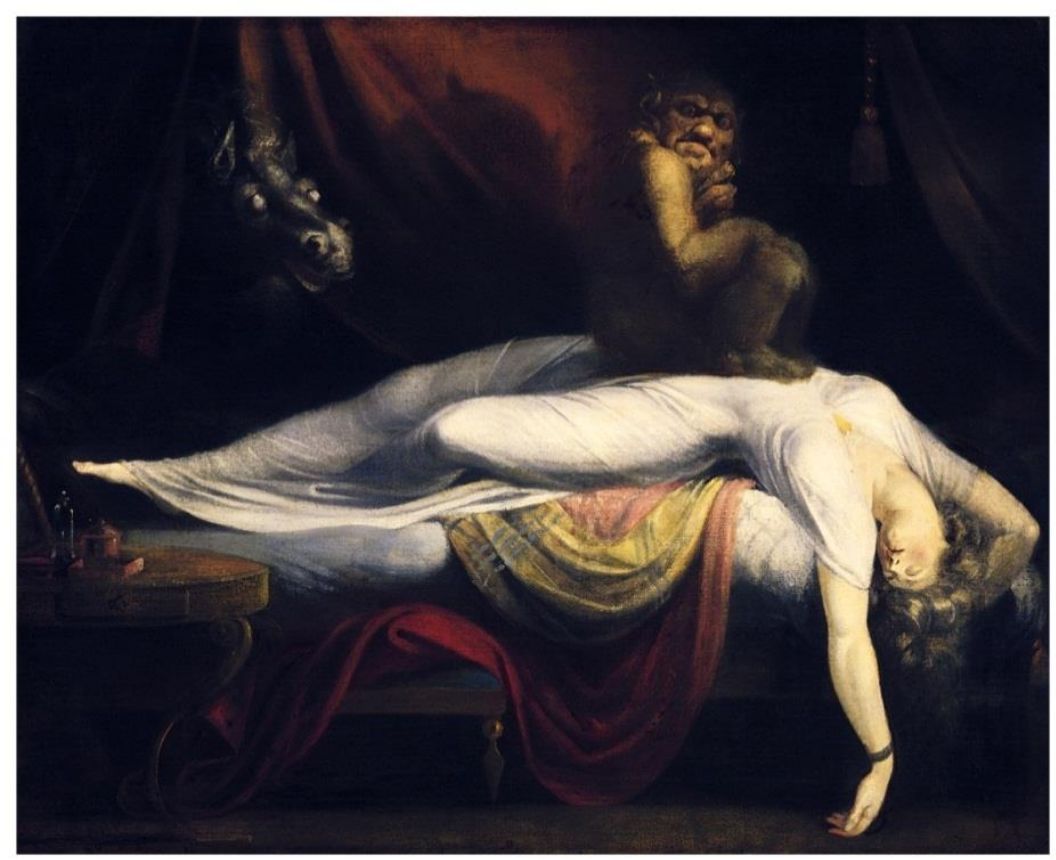

Fig 1. - Henri Fuseli, 'The Nightmare', 1781, Institute of Fine Arts, Detroit

Although he replaces the unheimliche with the English terms 'uncanny' and 'the modern unhomely', the architectural historian Anthony Vidler brings the unheimliche into a direct relationship with architecture in his seminal collection of essays entitled, The Architectural Uncanny: Essays in the Modern Unhomely (1992). Vidler induces poststructuralists' perspectives in architectural theory building, in which he identifies the uncanny to be a central and contemporary metaphor in architectural thinking and society. He also dedicates an essay to the emergence of gothic novels, which were common at the end of the $18^{\text {th }}$ century and the beginning of the $19^{\text {th }}$ century. Perhaps unusual for an historian, his essays have an intriguing and nonlinear structure as they intend to deconstruct history and architecture.

One could assert that Fuseli's painting foreshadows the unheimliche visions of Freud and Vidler. Do architectural experiences not often bring forward eerie feelings as they uneasily merge both the familiar (the sleeping lady and the interior) and the unfamiliar (the goblin)? The combinatorial phenomenon of familiarity and estrangement not only unsettles, but can also become, a creative agent that repositions the judgement and imagination for the receiver. Apparently, some phenomena, such as the hideous goblin, are not in tune with the environment. Out of tune, they become agents of anguish. This unexpected encounter leaves one bewildered: 'This is uncanny!'

\section{Unheimliche as an Existential Phenomenon and a Defamiliarizing Design Approach}

Beyond a psychoanalytical or a metaphoric perspective, the unheimliche can be examined as a phenomenon that can be encountered and experienced in the real world. In Sein und Zeit (1927), Martin Heidegger also makes reference to unheimlichkeit. However, Heidegger does not equate it solely to intellectual uncertainty or to repressed memories, as did Jentsch and Freud. He rather explores the existential dimension of unheimlichkeit by connoting it to 'homelessness': man has become a wandering being without a home. Only by building and inhabiting the world can one become a 'being-in-the-world' that properly belongs to the world. However, Heidegger's notion of 'being-towards-death' points to the inevitable encounter with death. Death becomes a possibility to develop one's freedom, whence emerges 'angst'. The significance for my research is that Heidegger-perhaps inappropriatelyportrays mortality and anguish as creative agents. In disclosing mortality, he identifies it to be 
a condition that both disrupts and triggers creativity. As he stated when speaking with Arne Grøn: 'In other words, through anguish man discovers freedom, his own freedom as a possibility' (Grøn, 2008).

In 'Architecture and Disjunction', Bernard Tschumi, architect and architectural theoretician, also discusses the unheimliche. He does acknowledge Heidegger's analysis and comes back to Freud, as well. He suggests what the discipline of architecture can mean for psychology: 'Architecture still has not begun to analyze the Viennese discoveries at the turn of the century, even if architecture might one day inform psychoanalysis more than psychoanalysis has informed architecture' (Tschumi, 1996, p.110). His design strategy is to willingly defamiliarizing in order to enhance perception of the familiar. This strategy investigates the value of transgression by repositioning (interior) architecture in the field of unexpectedness and future possibilities. In leaving the heimliche intimacy of the architectural discipline, one becomes unsettled. In this respect, he distinguishes between the enclosure of geborgenheit and the disclosure of ungeborgenheit. Whereas geborgenheit profoundly familiarizes, ungeborgenheit holds the promise of an unfamiliar and wider perspective, perhaps similar to the 'Shock of the Metropolis'.

What makes these diverse perspectives, as put forward by Tschumi, Heidegger, Freud and Vidler interconnected? One way could be to implement them into a specific design approach: the design approach of the unheimliche.

This design approach starts from the following critical question: does architectural education focus too much (one-sidedly) on a harmonious sense of belonging by insisting on heimliche forces, such as well-being? In my work as an educator of potential future interior architects, I have come to realize that students often assume an implicit need for a heimliche sense of reassurance in their respective designs. It seems that students are convinced that an architectural interior should respond to a need for belonging and well-being. One can assume that the primary task of interior architecture is to create a sense of protection. Why then wander off and encounter conflict by leaving the safety of this home?

At a lecture in Brussels, the philosopher Guy van Kerckhoven states something paradoxical on the institutional character of a design school: 'This house [the Architecture School of St Lucas] offers hospitality for a radical kind of homelessness that takes a grip at the root of architecture'(Van Kerckhoven, 2012).

As an educator at the St Lucas School of Architecture, I have organized a series of Research by Design Studios, the 'Onheimelijk Studio', organized to be completed at the end of the bachelor degree. In general, this Research by Design Studio approaches interior architecture as a learning process rather than as an affirmative final product. The Studio investigates the unheimliche with the following complexities in mind: the studio acknowledges the historical and 'Freudian' origins of the unheimliche (i.e. the psychoanalytical primacy of repressed memories), but also examines it as a 'Heideggerian' phenomenon that can be experienced in the world. Finally, the Studio takes a constructive stance by qualifying the unheimliche as a design approach with its own logic and agency. In so doing, it follows the defamiliarizing approach that Tschumi advocates.

Through 'recording, reconstructing and repositioning' unheimliche phenomena, this Studio aims at gaining another and critical understanding of what architectural interiors can mean and do in the light of the unheimliche. An awkward artefact (fig.2) issued at the fourth Onheimelijk Studio, Collective Memory, may shed a light on this question of agency. Together with the participating students, I inquired into the theme of the memory as an (un)reliable design tool (Beullens et al., 2012). The artefact is the result of a short and parallel collective endeavour by student co-researchers as part of a longer and larger scheme of 13 weeks. The basic design task could be qualified as 'Freudian': participants are asked to 'spatially reconstruct' a personal, unsettling memory. The design procedure of the artefact 
was rather unfamiliar: twenty designers line up in a non-preset chain and insert their individual design in an 'evolving' and collectively designed artefact.

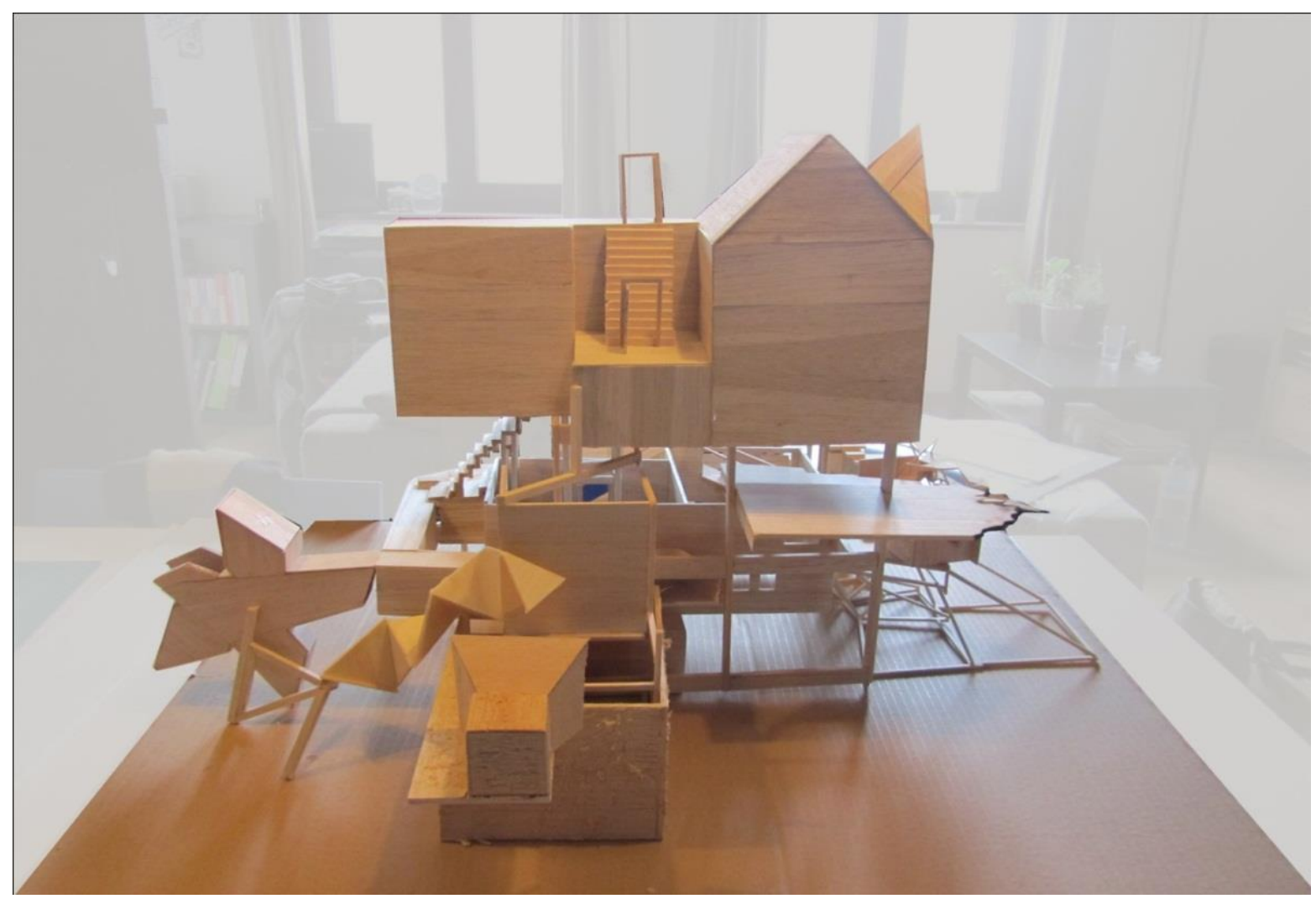

Fig 2. - Beullens et al, 'Collective Memory', 2012, St Lucas School of Arts, Ghent

This collective artefact embodies an intriguing switch that, at some point, participants of the Studio seem to make. This switch is reminiscent of Alain Findeli's assertion that there are 'two folds of the artefact' (2011), i.e. an artefact folds into a receiving (i.e. reception of the beholder-user) and conceiving (i.e. concept of the designer) side. In receiving a pre-existing design - a design that is already there-from a preceding colleague, a participating student becomes a 'receiver' of a design. Successively, the same receiving designer then conceives a new design and transfers it to the next one. It makes all participants stakeholders and coowners of this artefact: it becomes their proper belonging. Yet, in the encounter of 20 strange voices, the artefact becomes receptive to a rather short-lived ownership.

However, this design procedure and appropriation in itself may not be uncanny, but the ensuing result may be. Different than architects, interior architects often receive a building 'that is already there' in order to conceive of their interior design. They have to come to terms with reusing an existing building. In this particular collective design, student co-researchers have to continuously, and perhaps schizophrenically, 'double' themselves by incorporating what already exists. They become receivers of a building and then conceivers in the building. Uncannily, this happens by virtue of annihilating their receiving position immediately after conception and/or vice versa. To do so, they commit to an act of creative destruction. In other words, by affirming, and then destroying, their proper position as designers, each Studio participant eventually shifts from the uncritical belonging ('this is my artefact') towards the criticality of the encounter ('the artefact is not my design as it existed already; Hence, I critically engage with what I receive'). 
Out of tune, the 'artificial' artefact comes into being and (re)creates 20 traces of individual memories. It becomes a collective and successive design that silently and randomly assembles individual endeavours. This accumulation of design voices brings about a complexity that is, in the end of the design cycle, unfathomable and unheimliche to the beholder and to the individual designer. In this way, the lifeless object becomes animated with contradicting aspirations. It starts reciting 20 voices in a virtually non-existent language. The resulting artefact integrates and aggregates difference, thus becoming a potential source of the unheimliche.

Another uncanny element is the apparent loss of the self during this cooperative design process. As Richard Senett put it in Together: The Rituals, Pleasures and Politics of Cooperation, 'Cooperation always precedes individuation: ...we learn how to be together before we learn how to stand apart' $(2012$, p. 13). Hence, the self not only loses through cooperation, it is compensated by a sense of 'togetherness'. I would contend that the designer should allow contamination of his or her precious design endeavour by operating within a collective, and thus uncertain, logic. The supposed authorial authenticity is hereby sullen, yet in sharing it collectively the design becomes resistant to otherness.

One could perhaps sustain that this collective design — an almost marginal yet uncanny by-product - embodies an underlying and emergent network of objects, aspirations and contradicting concepts. By both pursuing and abandoning self-centred design paths, one engages in an intriguing perspective. This perspective may open an intriguing world of unknowing, i.e. the world of the unheimliche, whereby unpredicted possibilities may emerge in the temporal allowance of existential anguish.

\section{Concluding Remarks}

The architectural interior seems to be surrounded by an aura of tensions. These tensions seem to affect and infect spaces, institutions, disciplines, things and beings, both in unexpected and in conventional ways. In my view, this tension between belonging to a particular affiliation and unexpected experiential encounters has implications on existing and 'given' identities. These identities are knowingly or unknowingly contributed to beings (such as designers and beholders) and things (such as interiors and artefacts). As an unsettling phenomenon in architecture, the unheimliche explores the agencies of anticipations and affiliations. In other words, it explores the emergent faculties of existential anguish. The unheimliche pervades the complex state of beings and the things that occur in the world. It may transform and force contradictory aspirations into an uncanny coexistence and re-creation of what already exists.

The painting by Fuseli and the studio's collective artefact are, in reality, part of the same token: the former may be the artist's conscious and artistic attempt to provoke and encounter the unheimliche, while the latter artefact belongs to everybody and to nobody, an unheimliche by-product without proper receiver and conceiver. I would contend that the artefact unites fractions of Freud's, Heidegger's and Tschumi's aspirations.

Starting from a practice-based experience in teaching, the unheimliche embodies a specific design approach towards implementing existential anguish into interior architecture. As a residual by-product, the unheimliche can become productive while designing interiors. As the unforeseen occurs, a particular sense of the unheimliche starts to set in. It captivates the designer, who allows a temporary loss in control of the design. In empathically constructing unexpected identities in between the self and the other, the perception of the beholder and the conception of the interior designer can be altered.

Should education induce a sense of belonging, or should it rather induce the possibilities of the encounter? Should an architectural education remain institutional, or can it exceed its traditional borders in becoming ex-stitutional? I believe it has to do both. Not only 
the making of interiors or the apparition of awkward artefacts, but also teaching, may offer a platform to explore the (re)creative working of existential anguish.

Unheimlichkeit in interior architecture embraces the puzzling coexistence of beings and things in order to identify them and transform them in a particular strength. This does not happen by an exclusive return to an idealized past or by clinging to fixed identities, but rather by including unheimliche strategies for the wanderer who desires (or not) to inhabit an uncertain future.

\section{Karel Deckers}

Educator and architect, PhD Researcher

Chalmers University of Technology, Göteborg, Architecture

KUL Leuven, Leuven, Architecture

Email address: karel.deckers@kuleuven.be

\section{References}

Beullens, A., Bolcaen, J., Coelus, A., Coppelmans, S., Coppens, K., Cornelissen, J., Willemse, J. (2012). Onheimelijk IV: Collective memory. K. Deckers (Ed.). Ghent, Belgium: St Lucas School of Arts.

Findeli, A. (2011). Searching for design research questions: Some conceptual clarifications. Brussels, Belgium: St Lucas School of Architecture.

Freud, S. (2003 [1919]). The uncanny (D.McClintock, Trans.). London, England: Penguin Books.

Grøn, A. (2008). The concept of anxiety in Sören Kierkegaard. Macon, GA: Mercer University Press.

Heidegger, M. (1927). Zijn en Tijd (Sein und Zeit). Leuven, Belgium: Kritak.

Jentsch, E. (1906). Zur psychologie des unheimlichen. Psychiatrisch-Neurologische Wochenschrift 8(22), 195-198.

Sennett, R. (2012). Together: The rituals, pleasures and politics of cooperation. London. England: Penguin Books.

Sloterdijk, P. (2005). Sferen. Amsterdam, Netherlands: Boom.

Tschumi, B. (1996). Architecture and disjunction. London, England: MIT Press.

Van Kerckhoven, G. (2012). De profundis, architectuur als geheim. Brussels, Belgium: St Lucas School of Architecture. (unpublished manuscript)

Vidler, A. (1992). The architectural uncanny: Essays in the modern unhomely. Cambridge, MA: MIT Press. 